\title{
PENERAPAN PEMBELAJARAN JARAK JAUH BERBASIS GOOGLE CLASSROOM UNTUK MENINGKATKAN KEMAMPUAN KOMUNIKASI MATEMATIS SISWA
}

\author{
Ika Sriyanti \\ STKIP Subang \\ Ikasriyanti99@gmail.com
}

\begin{abstract}
ABSTRAK
Tujuan dari peneliti adalah untuk mengetahui peningkatan kemampuan komunikasi matematis siswa dengan menggunakan Pembelajaran Jarak Jauh berbasis Google Classroom. Di masa pandemi Covid-19 ini tidak bisa melangsungkan pembelajaran tatap muka, maka dipilih penelitian menggunakan Pembelajaran Jarak Jauh berbasis Google Classroom. Penelitian ini merupakan penelitian Ex Post Facto. Populasi dalam penelitian ini adalah seluruh kelas VII SMPN Purwadadi dengan sampel kelas VII C. Instrumen dalam penelitian ini adalah soal uraian berupa tes kemampuan komunikasi matematis berupa tujuh butir. Hasil tes diolah menggunakan Software SPSS 17.0 For Windows. Berdasarkan hasil dari uji-T sebelum dan sesudah pembelajaran sebesar 0,000 taraf signifikansi $\alpha<0,05$ artinya pada taraf kepercayaan 95\% kemampuan komunikasi matematis siswa sesudah diterapkan Pembelajaran Jarak Jauh berbasis Google Classroom lebih baik dibandingkan sebelum diterapkan Pembelajaran Jarak Jauh berbasis Google Classroom. Sehingga terdapat peningkatan antara sebelum dan sesudah diterapkan Pembelajaran Jarak Jauh berbasis Google Classroom. Sedangkan berdasarkan hasil N-Gian sebesar 0,19 dimana jika diklasifikasikan nilai tersebut berada pada tingkatan rendah. Instrumen nontes yang digunakan dalam penelitian ini berupa angket dengan tujuan untuk mengetahui kemandirian belajar siswa terhadap pembelajaran matematika. Berdasarkan hasil perhitungan, diperoleh persentase rata-rata jawaban siswa secara keseluruhan sebesar $32.53 \%$ artinya hampir setengahnya siswa telah memiliki kemandirian dalam belajar matematika.
\end{abstract}

Kata Kunci : Pembelajaran Jarak Jauh, Google Classroom, Komunikasi Matematis, Kemandiriaan.

\begin{abstract}
The purpose of the researcher is to determine the improvement of students' mathematical communication skills using Google Classroom-based Distance Learning. During the Covid-19 pandemic, it was not possible to carry out face-to-face learning, so research was chosen using Google Classroom-based Distance Learning. This research is an Ex Post facto research. The population in this study were all VII graders of SMPN Purwadadi with a sample of class VII C. The instrument in this study was a question of description in the form of a mathematical communication ability test in the form of seven items. The test results were processed using SPSS 17.0 Software For Windows. Based on the results of the T-test before and after learning of 0.000 , the significance level $<0.05$, meaning that at the $95 \%$ confidence level students' mathematical communication skills after Google Classroom-based Distance Learning was implemented were better than before Google Classroombased Distance Learning was applied. So that there is an increase between before and after the implementation of Google Classroom-based Distance Learning. Meanwhile, based on the results of $\mathrm{N}$-Gian, the $\mathrm{N}$-Gain value is 0.19 , where if classified the value is at a low level. The non-test instrument used in this study was in the form of a questionnaire with the aim of knowing students' independence in learning mathematics. Based on the calculation results, the average percentage of students' answers as a whole is $32.53 \%$, meaning that almost half of the students already have independence in learning mathematics.
\end{abstract}

Keywords : Google Classroom, Distance Learning, Mathematical Communication, SelfRegulated Learning 


\section{PENDAHULUAN}

Populasi menurut Sugiyono (Lestari dan Yudhanegara, 2015, hlm 101) 'populasi adalah wilayah generalisasi yang terdiri atas obyek/subyek yang mempunyai kuantitas dan karakteristik tertentu yang ditetapkan oleh peneliti untuk dipelajari dan kemudian ditarik kesimpulannya'. Menerurut Sugiono (Lestari dan Yudhanegara, 2015, hlm 101) 'sampel adalah bagian dari jumlah dan karakteristik yang dimiliki oleh populasi tersebut'. Dalam penelitian ini pengambilan sampel yang terpilih yaitu siswa kelas VII. Adapun populasi dalam penelitian adalah seluruh siswa kelas VII SMP Negeri 3 Purwadadi.

Pembelajaran ialah suatu proses penyaluran data ataupun pesan dari pendidik ke peserta didik yang direncanakan, dilaksanakan, serta dievaluasi secara sistematis yang dicoba di sekolah ataupun di luar sekolah dimana akan terjalin interaksi antara keduanya. Sedangkan Pembelajaran yang bermakna ialah proses belajar mengajar yang diharapkan untuk siswa dimana siswa bisa ikut serta langsung dalam proses pembelajaran dan menciptakan langsung pengetahuan tersebut.

Menurut Sumarno (Ranti, 2015) 'dalam kegiatan hidupnya setiap orang akan terlibat matematika'. Salah satu tujuan pembelajaran matematika yaitu agar siswa memiliki kemampuan mengembangkan dan menggunakan matematika dalam memecahkan masalah dan mampu mengkomunikasikan ide atau gagasan dengan menggunakan simbol, tabel, diagram dan media lain. Tetapi, pada kenyataannya kalau hasil belajar matematika yang dicapai siswa masih rendah. Rendahnya hasil belajar matematika siswa diprediksi diakibatkan oleh kesusahan menguasai matematika. Matematika masih dikira sebagai mata pelajaran yang susah.

Mansyur dan Fathani (Oktavian, 2019) 'berdasarkan hasil penelitian di Indonesia, ditemukan bahwa tingkat penguasaan peserta didik dalam matematika pada semua jenjang pendidikan masih sekitar 34\%'. Untuk meningkatkan kemampuan siswa terhadap matematika tugas serta peran guru bukan lagi sebagai pemberi data/informasi, namun sebagai pendorong siswa belajar supaya bisa menyusun sendiri pengetahuan melalui bermacam kegiatan seperti pemecahan masalah, penalaran serta komunikasi. Dalam kurikulum 2013 Lampiran 3 Permendikbud No. 58 (Kemendikbud, 2014, hlm. 325) "tujuan pembelajaran matematika salah satunya adalah siswa mampu Mengkomunikasikan gagasan, penalaran serta mampu menyusun bukti matematika dengan menggunakan kalimat lengkap, simbol, tabel, diagram, atau media lain untuk memperjelas keadaan atau masalah.

Komunikasi matematika merupakan salah satu kompetensi yang sangat penting selama proses pembelajaran, komunikasi gagasan matematika bisa berlangsung antar guru 
dengan siswa, antar buku dengan siswa, dan antar siswa dengan siswa, agar proses pembelajaran dapat berlangsung demi tercapainya tujuan pembelajaran. Abdulhak (Ansari, 2018, hlm 12) mengemukakan 'komunikasi yaitu proses penyampaian pesan dari pengirim pesan melalui saluran tertentu untuk tujuan tertentu'. Pengertian komunikasi secara umum yaitu suatu cara untuk menyampaikan pesan dari pembawa pesan ke penerima pesan untuk memberitahukan pendapat baik itu secara langsung atau lisan (percakapan tatap muka pidato tatap muka dan lain-lain) maupun tidak langsung melalui media atau tulisan (berbicara melalui telepon, mendengarkan berita di radio atau televisi dan lain-lain). Lewat komunikasi suatu ide ataupun gagasan dapat didiskusikan, diperbaiki serta dikembangkan. Salah satu kemampuan komunikasi yang harus dimiliki siswa adalah kemampuan komunikasi matematika. Bersumber pada kenyataan di lapangan bahwa kemampuan komunikasi matematis siswa masih lemah serta jauh dari harapan, siswa kesulitan dalam mengungkapkan atau menjelaskan gagasan dalam bentuk tulisan maupun gambar, serta siswa kurang berani dalam mengemukakan ide matematis maupun pendapatnya sendiri.

Kemampuan komunikasi matematis bisa berjalan dengan baik, apabila diciptakan suasana pembelajaran matematika yang kondusif serta menarik sehingga bisa memaksimalkan kemampuan siswa dalam membaca, menulis, mendengarkan, mendiskusikan, memberikan jawaban atau alasan, serta mengemukakan pendapat ataupun ide. Maka diperlukan kemampuan guru untuk memilih metode pembelajaran yang sesuai agar dapat menumbuhkembangkan kemampuan pemahaman dan komunikasi matematis siswa. Namun pembelajaran biasa yang biasa dilakukan di sekolah secara tatap muka langsung tidak dapat dilaksanakan pada saat pandemic Covid-19 ini.

Pembelajaran Jarak Jauh menurut Munir (2009) adalah 'ketika proses pembelajaran tidak terjadinya kontak dalam bentuk tatap muka langsung antar pengajar dan pembelajar, sehingga komunikasi antara tenaga pengajar serta siswa harus difasilitasi dengan media, elektronik, dan media-media lain'. Surat edaran dari Kementrian Pendidikan dan juga Kebudayaan No 15 tahun 2020 pedoman penyelenggaraan pembelajaran dari rumah dalam masa pandemi Covid-19, berisi tentang "tujuan penerapan belajar dari rumah yaitu untuk memastikan pemenuhan hak peserta didik untuk memperoleh layanan pendidikan selama Covid-19, melindungi masyarakat satuan pendidikan terhadap dampak buruk dari Covid-19, menghindari penyebaran dan juga penularan psikologis bagi pendidik, peserta didik, serta orang tua". Di masa pandemic Covid-19 ini pemerintah menerapkan kebijakan pembatasan sosial berskala besar (PSBB) untuk menekan penyebaran virus ini. Adanya aturan dari pemerintah tersebut Semua sekolah diliburkan, pembelajaran tatap muka di sekolah 
ditiadakan dan diganti dengan menggunakan Pembelajaran Jarak Jauh, salah satu pembelajaran yang digunakan sekolah salah satunya yaitu menggunakan aplikasi Google Classroom.

Google Classroom ialah platform belajar dan mengajar secara virtual yang dapat dicoba dimana pun. Aplikasi keluaran Google ini bisa menjadi perantara interaksi antara guru dengan siswa untuk memberikan materi sampai tes. Kelebihan Google Classroom menurut Putri dan Dewi (2019) yaitu Google Classroom sesungguhnya ramah lingkungan itu karena dirancang untuk membantu guru membuat dan mengumpulkan tugas tanpa kertas, hemat waktu karena memungkinkan pengajar membuat, memeriksa, dan menilai tugas dengan cepat di satu tempat serta aplikasinya mudah diakses dan dapat digunakan oleh instruktur dan peserta didik.

Menurut Yazdi (Kurniawan, 2020) "Pembelajaran Jarak Jauh memiliki fokus utama pada kemandirian siswa pada waktu tertentu dan tanggung jawab terhadap belajarnya". Untuk berhasil dalam Pembelajaran Jarak Jauh diperlukan kemandirian belajar. Faktor lain yang menentukan keberhasilan siswa dalam menerima pelajaran adalah kemampuan kemandirian belajar. Kemandirian belajar dalam pembelajaran itu penting agar siswa memiliki rasa tanggung jawab disiplin juga mengatur dirinya, dan mengembangkan kemampuannya dalam belajar atas kemauannya sendiri. Kemandirian siswa dalam belajar terlihat dari siswa ikut serta dalam menentukan tujuan pembelajaran, cara belajar dan mengevaluasi hasil belajarnya sendiri.

Berdasarkan uraian di atas, peneliti tertarik untuk mengetahui kemampuan komunikasi matematis siswa dengan metode yang tepat sebagai suatu alternatif pembelajaran agar meningkatkan kemampuan komunikasi matematis siswa melalui penelitian yang diberi judul "Penerapan Pembelajaran Jarak Jauh Berbasis Google Classroom Untuk Meningkatkan Kemampuan Komunikasi Matematis Siswa”.

\section{METODE PENELITIAN}

Populasi menurut Sugiyono bahwa 'populasi adalah wilayah generalisasi yang terdiri atas obyek/subyek yang mempunyai kuantitas dan karakteristik tertentu yang ditetapkan oleh peneliti untuk dipelajari dan kemudian ditarik kesimpulannya'. Menurut Sugiono (Lestari dan Yudhanegara, 2015, hlm 101) 'sampel adalah bagian dari jumlah dan karakteristik yang dimiliki oleh populasi tersebut'. Dalam penelitian ini pengambilan sampel yang terpilih yaitu siswa kelas VII. Adapun populasi dalam penelitian adalah seluruh siswa kelas VII SMP Negeri 3 Purwadadi. 
Penelitian ini bersifat Ex post Facto, yaitu jenis penelitian yang variabel independennya merupakan peristiwa yang sudah terjadi. Menurut Sugiyono (Lestari dan Yudhanegara, 2015, hlm 114), 'Ex post Facto merupakan suatu penelitian yang dilakukan untuk meneliti peristiwa yang telah terjadi dan kemudian merunut ke belakang untuk mengetahui faktor-faktor yang dapat menyebabkan timbulnya kejadian tersebut'. Dalam penelitian ini menggunakan Ex post Facto karena pada saat ini terjadi penyebaran virus Covid-19 menyebabkan tidak bisa melakukan penelitian eksperimen. Instrument yang digunakan dalam penelitian ini adalah instrument tes dan instrument non-test. Adapun tipe tes dalam uraian ini adalah tes subjektif atau uraian. Instrumen tes yang digunakan dalam penelitian ini adalah tes kemampuan komunikasi matematis siswa yang terdiri dari tujuh soal terdiri dari tujuh indikator komunikasi yang diambil dari penelitian yang dilakukan oleh Rahayu (2017).

Sedangkan menurut (Rahayu, 2017) "instrumen nontes biasanya digunakan sebagai alat untuk mengukur aspek afektif atau psikomotorik". Instrumen non-tes yang digunakan dalam penelitian ini meliputi angket. Angket atau kuesioner digunakan untuk mengetahui kemandirian belajar siswa terhadap pembelajaran matematika dengan menggunakan Pembelajaran Jarak Jauh berbasis Google Classroom. Angket diberikan setelah proses pembelajaran selesai dilakukan, sehingga dapat diketahui kemandirian belajar siswa mengenai Pembelajaran Jarak Jauh berbasis Google Classroom. Angket siswa adalah data yang bersifat kualitatif. Data yang diperoleh akan dianalisis dan diambil kesimpulannya. Angket diberikan kepada siswa untuk mengetahui kemandirian belajar siswa terhadap pembelajaran matematika menggunakan Pembelajaran Jarak Jauh berbasis Google Classroom. (Lestari dan Yudhanegara, 2015) penentuan persentase jawaban siswa untuk masing-masing per item pernyataan dalam angket, digunakan Kriteria sebagai berikut.

Tabel 1 Kriteria Penafsiran Persentase Jawaban Angket

\begin{tabular}{cc}
\hline Persentase jawaban & Interpretasi \\
\hline $\mathrm{P}=0 \%$ & Tak seorangpun \\
$0 \%<\mathrm{P} \leq 25 \%$ & sebagian kecil \\
$25 \%<\mathrm{P} \leq 50 \%$ & Hampir setengahnya \\
$\mathrm{P}=50 \%$ & Setengahnya \\
$50 \%<\mathrm{P} \leq 75 \%$ & Sebagian besar \\
$75 \%<\mathrm{P} \leq 100 \%$ & Hampir seluruhnya \\
$\mathrm{P}=100 \%$ & Seluruhnya \\
\hline
\end{tabular}

Kemudian dilakukan analisis secara deskriptif. Analisis secara deskriptif dilakukan dengan cara menguraikan persentase jawaban responden berdasarkan kriteria penafsiran 
persentase jawaban angket yang terdiri dari analisis per item pernyataan dan analisis secara keseluruhan.

Tes kemampuan komunikasi matematika diberikan kepada subjek penelitian bertujuan untuk mengukur sejauh mana kemampuan komunikasi matematis siswa melalui materi yang diberikan. Ada dua bagian tes yang dilakukan, ada pre-test atau tes awal yang dilakukan pada pertama kali penelitian tujuannya untuk mengetahui sejauh mana kemampuan komunikasi matematika dan pos-test atau tes akhir yang diberikan setelah dilakukan pembelajaran.

Menurut Arikunto (Rahayu, 2017) yang dimaksud teknik pengumpulan data adalah "cara yang digunakan oleh peneliti dalam pengumpulan data penelitinya". Berdasarkan pengertian tersebut dapat dikatakan bahwa metode penelitian adalah cara yang dipergunakan untuk mengumpulkan data yang diperlukan dalam penelitian. Teknik pengumpulan data yang diolah pada penelitian ini adalah hasil data pretest (tes awal) dan postest (tes akhir). Data yang telah diperoleh dari hasil tes awal dan tes akhir akan diuji dengan menggunakan uji statistik. Dengan menggunakan Software SPSS 17.0 For Windows, dengan langkah sebagai berikut; Uji normalitas dilakukan untuk mengetahui apakah data yang diperoleh berdistribusi normal atau tidak. Uji normalitas adalah melakukan perbandingan antara data yang kita miliki dengan data berdistribusi normal yang memiliki mean dan standar deviasi yang sama. Uji perbedaan dua rerata menggunakan uji Wilcoxon dengan bantuan Software SPSS 17.0 For Windows. Uji N-Gain merupakan data yang diperoleh dengan cara membandingkan selisih skor pretest dan posttest.

\section{HASIL DAN PEMBAHASAN}

Penelitian ini bertujuan untuk mengetahui peningkatan kemampuan komunikasi matematis siswa. Penelitian ini dilaksanakan di salah satu SMP Negeri yang berada di daerah Purwadadi yang dilaksanakan pada 24 Agustus sampai 24 September dengan mengambil sampel kelas VII C. Sebelum pembelajaran dilakukan terlebih dahulu siswa mengikuti tes awal (pretest) yang bertujuan untuk mengukur kemampuan komunikasi matematika awal siswa kemudian dilakukan proses pembelajaran dengan pokok bahasan himpunan sampai tersampaikan dan terakhir dilakukan tes akhir (posttest) yang bertujuan untuk mengetahui peningkatan kemampuan komunikasi matematis siswa.

\section{Analisis Data Pretest dan Postest Kemampuan Komunikasi Matematis Siswa}

Analisis data tes dilakukan untuk mengetahui kemampuan komunikasi matematika sebelum dan sesudah diberikan perlakuan yaitu penerapan Pembelajaran Jarak Jauh berbasis 
Google Classroom. Tujuan diberikan pretest dan postest ini adalah untuk mengetahui apakah terdapat perbedaan yang signifikan terhadap kemampuan komunikasi matematika.

Setelah dilakukan perhitungan terhadap skor Pretest dan Posttest maka diperoleh rata-rata, skor tertinggi, skor terendah, varians dan standar deviasi. Deskripsi data tersebut disajikan dalam Tabel 2.

Tabel 2 Statistik data pretest dan posttest

\begin{tabular}{cccccc}
\hline & N & Minimum & Maximum & Mean & Std. deviation \\
\hline Sebelum & 20 & 0 & 6 & 2.15 & 1.387 \\
Sesudah & 20 & 3 & 21 & 6.95 & 5.680 \\
\hline
\end{tabular}

Berdasarkan Tabel 1.1 dapat dilihat bahwa rata-rata pretest adalah 2,15 sedangkan rata-rata postest adalah 6,95. Standar deviasi pretest adalah 1,387 sedangkan standar deviasi postest adalah 5,680. Nilai minimum pretest adalah 0 sedangkan nilai minimum postest adalah 3. Nilai maksimum pretest adalah 6 sedangkan nilai maksimum postest adalah 21 . Hal tersebut mengindikasikan bahwa kemampuan komunikasi matematis siswa setelah diberikan Pembelajaran Jarak Jauh berbasis Google Classroom lebih baik dibandingkan dengan kemampuan komunikasi matematis siswa sebelum diberikan Pembelajaran Jarak Jauh berbasis Google Classroom.

\section{Uji Normalitas Skor Pretest dan Postest}

Uji normalitas dilakukan untuk mengetahui apakah data yang diperoleh berdistribusi normal atau tidak. Uji normalitas dalam penelitian ini dilakukan dengan uji Shapiro-wilk dengan mengambil nilai signifikansi 0.05 dan penghitungannya dilakukan dengan menggunakan Software SPSS 17.0 For Windows.

Tabel 3 Hasil Uji Normalitas Skor Pretest dan Postest Kemampuan Komunikasi

Matematis Siswa

\begin{tabular}{cccc}
\hline Tes & \multicolumn{3}{c}{ Shapiro-Wilk } \\
\cline { 2 - 4 } & Statistic & Df & Sig. \\
\hline Sebelum & .886 & 20 & .023 \\
Sesudah & .643 & 20 & .000 \\
\hline
\end{tabular}

Berdasarkan Tabel 3 uji normalitas untuk pretest diperoleh nilai signifikan $0.023<$ 0.05 maka $H_{o}$ ditolak yang artinya bahwa data skor pretest kemampuan komunikasi matematis siswa tersebut tidak berdistribusi normal. Sedangkan untuk postest diperoleh nilai signifikan $0.000<0.05$ maka $H_{o}$ ditolak yang artinya bahwa data skor postest kemampuan komunikasi matematis siswa tersebut tidak berdistribusi normal. Karena data 
Pretest dan Postest tidak berdistribusi normal maka selanjutnya digunakan uji perbedaan dua rerata dengan menggunakan uji non-parametris yaitu uji Wilcoxon.

\section{Uji Perbedaan Dua Rerata Skor Pretest dan Posttest}

Berdasarkan uji normalitas yang telah diperoleh sebelumnya bahwa data skor pretest dan postest tidak berdistribusi normal. Oleh karena itu untuk menguji perbedaan dua rerata menggunakan uji Wilcoxon dengan bantuan Software SPSS 17.0 For Windows.

Tabel 4 Hasil Uji Perbedaan Dua Rerata Skor Pretest Dan Postest Kemampuan Komunikasi Matematis Siswa

Test Statistics ${ }^{\mathrm{b}, \mathrm{O}}$

\begin{tabular}{|lll|r|}
\hline & & $\begin{array}{r}\text { sesudah - } \\
\text { sebelum }\end{array}$ \\
\hline$Z$ & & & $-3.938^{a}$ \\
Asymp. Sig. (2-tailed) & & .000 \\
Monte Carlo Sig. (2-tailed) & Sig. & .000 \\
& $95 \%$ Confidence Interval & Lower Bound & .000 \\
& & Upper Bound & .000 \\
Monte Carlo Sig. (1-tailed) & & Sig. & .000 \\
& $95 \%$ Confidence Interval & Lower Bound & .000 \\
& & Upper Bound & .000 \\
\hline
\end{tabular}

a. Based on negative ranks.

b. Wilcoxon Signed Ranks Test

c. Based on 10000 sampled tables with starting seed 2000000 .

Karena pengujian yang dilakukan adalah uji satu pihak (uji pihak kanan) maka berdasarkan Tabel 4.3 nilai Sig. yang digunakan adalah Monte Carlo Sis. (1-tailed) yaitu sebesar 0.000. Karena nilai Sig. $<0.05$, maka $H_{o}$ ditolak, artinya pada taraf kepercayaan 95\% kemampuan komunikasi matematis siswa sesudah diterapkan Pembelajaran Jarak Jauh berbasis Google Classroom lebih baik dibandingkan sebelum diterapkan Pembelajaran Jarak Jauh berbasis Google Classroom. Hal ini dapat diartikan pembelajaran matematika menggunakan Pembelajaran Jarak Jauh berbasis Google Classroom dapat meningkatkan kemampuan komunikasi matematis siswa.

\section{Analisis Data N-Gain}

Pada pembahasan sebelumnya uji perbedaan dua rerata menggunakan uji Wilcoxon didapat kesimpulan bahwa kemampuan komunikasi matematis siswa sesudah diterapkan Pembelajaran Jarak Jauh berbasis Google Classroom lebih baik dibandingkan sebelum diterapkan Pembelajaran Jarak Jauh berbasis Google Classroom, dengan demikian dapat diartikan bahwa terdapat peningkatan. Untuk mengetahui tingkat kriteria peningkatan apakah berada pada tingkatan rendah, sedang atau tinggi, maka dilakukan analisis N-Gain. 
Data N-Gain merupakan data yang diperoleh dengan cara membandingkan selisih skor pretest dan postest dengan selisih skor maksimum ideal serta skor postest.

Tabel 5 Rekapitulasi N-Gain Ternormalisasi Kemampuan komunikasi Matematis Siswa

\begin{tabular}{ccccccc}
\hline $\begin{array}{c}\text { Tingkat } \\
\text { N-Gain }\end{array}$ & Frekuensi & $\%$ & $\begin{array}{c}\text { Rerata } \\
\text { N-Gain }\end{array}$ & Kualifikasi & $\begin{array}{c}\text { Skor } \\
\text { Tertinggi }\end{array}$ & $\begin{array}{c}\text { Skor } \\
\text { Terendah }\end{array}$ \\
\hline Tinggi & 1 & $5 \%$ & & & & \\
Sedang & 2 & $10 \%$ & 0.19 & Rendah & 0.71 & 0.04 \\
Rendah & 17 & $85 \%$ & & & & \\
\hline
\end{tabular}

Berdasarkan Tabel 4.4 bahwa nilai minimum N-Gain $=0,04$ dan nilai maksimumnya 0,71. Sedangkan untuk tingkat N-Gian memperlihatkan bahwa kualifikasi peningkatan kemampuan komunikasi matematis siswa dari tiap data individu adalah 17 0rang siswa (85\%) mendapatkan klasifikasi peningkatan yang rendah, 2 Orang siswa mendapatkan (10\%) kualifikasi peningkatan sedang dan 1 Orang siswa (5\%) mendapatkan kualifikasi peningkatan tinggi. Nilai N-Gain sebesar 0,19, dimana jika diklasifikasikan nilai tersebut berada pada tingkatan rendah.

\section{Kemandirian siswa}

Analisis skala kemandirian siswa diklasifikasikan berdasarkan per item pernyataan untuk mengetahui persentase kemandirian belajar. hasil angket ini dianalisis dan diolah secara deskriptif dengan bantuan Microsoft Excel dengan jumlah responden 20 siswa.

Tabel 6 Persentase Rata-Rata Kemandirian Belajar Siswa

\begin{tabular}{clc}
\hline No & \multicolumn{1}{c}{ Pernyataan } & $\begin{array}{c}\text { Presentasi rata-rata } \\
\text { per item }\end{array}$ \\
\hline 1 & $\begin{array}{l}\text { Pembelajaran seperti ini membuat anda dalam } \\
\text { belajar tidak bergantung pada orang lain }\end{array}$ & $34.50 \%$ \\
2 & $\begin{array}{l}\text { Saya terlambat mengumpulkan tugas yang } \\
\text { diberikan oleh guru }\end{array}$ & $27.00 \%$ \\
3 & $\begin{array}{l}\text { Apakah anda diingatkan oleh orang tua anda } \\
\text { untuk belajar matematika }\end{array}$ & $30.00 \%$ \\
4 & $\begin{array}{l}\text { Apakah anda terpacu setiap guru anda } \\
\text { mengingatkan murid-muridnya untuk belajar } \\
\text { matematika }\end{array}$ & $45.00 \%$ \\
5 & $\begin{array}{l}\text { Pembelajaran seperti ini membuat anda untuk } \\
\text { aktif dalam mencari tugas yang harus dikerjakan }\end{array}$ & $34.00 \%$ \\
6 & $\begin{array}{l}\text { Saya malas mempelajari matematika di rumah } \\
\text { Apakah anda sering tidak mengumpulkan tugas, } \\
\text { apabila guru matematika anda memberikan tugas } \\
\text { dan menyuruh dikumpulkan }\end{array}$ & $31.50 \%$ \\
8 & $\begin{array}{l}\text { Saya mengerjakan tugas matematika dengan } \\
\text { bersungguh-sungguh } \\
\text { Apakah anda belajar matematika dari dorongan } \\
\text { anda sendiri }\end{array}$ & $26.50 \%$ \\
& $27.00 \%$
\end{tabular}


10 Apakah anda mengerjakan soal-soal matematika yang ada di buku-buku referensi tanpa perintah $27.00 \%$ siapapun

11 Apakah anda mengandalkan teman anda dalam mengerjakan tugas-tugas di sekolah

12 Saya menganggap soal yang sulit sebagai tantangan

13 Jika anda tidak dapat menyelesaikan tugas matematika, apakah anda membiarkannya saja

14 Pembelajaran seperti ini membuat anda mengumpulkan tugas dengan tepat waktu

$40.50 \%$

15 Apakah anda merasa putus asa ketika ada soal matematika yang sulit

$26.00 \%$

16 Saya belajar sesempatnya saja ketika ada tugas dari guru

17 Setiap kali akan menempuh ujian matematika, apakah anda berfikir bahwa anda pasti berhasil

18 Apakah anda merasa bahwa keberhasilan matematika anda ditentukan oleh anda sendiri

$28.50 \%$

19 Apabila diadakan ulangan harian, apakah anda mencontek pekerjaan teman anda

$30.50 \%$

20 Saya bertanya kepada teman ketika ada materi pelajaran yang belum dipahami

Persentase Rata-Rata Secara Keseluruhan

$54.50 \%$

$32.53 \%$

\section{Pembahasan}

Berdasarkan hasil analisis penelitian didapat bahwa kemampuan awal sebelum diberikan perlakuan (Pretest) mendapat rata-rata 2,15. Hasil analisis penelitian yang didapatkan setelah mendapat perlakuan (Postest) dengan menggunakan Pembelajaran Jarak Jauh berbasis Google Classroom mendapat 6,95. Pembelajaran Jarak Jauh berbasis Google Classroom lebih baik dibandingkan dengan kemampuan komunikasi matematis siswa sebelum diberikan Pembelajaran Jarak Jauh berbasis Google Classroom. Hasil perhitungan $\mathrm{N}$-Gain Berdasarkan Tabel 1.4 bahwa nilai minimum $\mathrm{N}-$ Gain $=0,04$ dan nilai maksimumnya 0,71. Sedangkan untuk tingkat N-Gian memperlihatkan bahwa kualifikasi peningkatan kemampuan komunikasi matematis siswa dari tiap data individu adalah 17 Orang siswa (85\%) mendapatkan klasifikasi peningkatan yang rendah, 2 0rang siswa mendapatkan (10\%) kualifikasi peningkatan sedang dan 1 Orang siswa (5\%) mendapatkan kualifikasi peningkatan tinggi. Nilai N-Gain sebesar 0,19, dimana jika diklasifikasikan nilai tersebut berada pada tingkatan rendah.

Dari hasil perhitungan Pretest dan Postest kemampuan komunikasi matematis siswa dengan penggunaan Pembelajaran Jarak Jauh Berbasis Google Classroom di SMP NEGERI 1 Purwadadi terbilang rendah. Pada soal no 6 dan soal no 7 pencapaian skor maksimal pada 
per soal itu 4 belum tercapai. Temuan peneliti di lapangan setelah mewawancarai beberapa siswa adalah siswa merasa kesulitan dengan Pembelajaran Jarak Jauh berbasis Google Classroom ini, karena pembelajarannya tidak tatap muka langsung jadi siswa merasa kesulitan dalam mempelajari materi yang diberikan oleh guru. Siswa sering merasa kebingungan pada saat menerima materi atau tugas karena siswa harus mencari sendiri pembahasan yang cocok dengan materi atau tugas yang diberikan oleh guru dan beberapa siswa masih belum bisa belajar mandiri secara optimal. Siswa kurang berinteraksi dengan guru ketika ada materi yang tidak dimengerti atau ada tugas yang tidak dimengerti siswa tidak mengumpulkan tugas tersebut. Sejalan dengan penelitian yang dilakukan oleh Purti dan Dewi (2019) adanya peningkatan menggunakan Pembelajaran Jarak Jauh berbasis Google Classroom meskipun tidak terlalu signifikan. Jadi, penelitian menggunakan Pembelajaran Jarak Jauh berbasis Google Classroom ini ada peningkatan tetapi tidak terlalu signifikan bisa rendah atau sedang. Menurut teori Ausubel (Isjoni, 2019) pelajaran yang dipelajari haruslah bermakna dengan Pembelajaran Jarak Jauh berbasis Google Classroom materi atau tugas yang diberikan oleh guru seharusnya siswa bisa mengembangkan sendiri materi tersebut bisa mencari informasi sebanyak banyaknya misalnya di internet jadi banyak sumber yang didapat siswa sehingga siswa lebih mengerti terhadap materi yang diberikan oleh guru karena menggali sendiri. Komunikasi dalam belajar itu tidak harus tatap muka langsung dengan guru, tetapi komunikasi juga bisa dilakukan secara tidak langsung misalnya melalui media atau tulisan misalnya dengan membuka video di YouTube untuk mencari informasi materi yang di inginkan.

Adapun persentase rata-rata jawaban siswa untuk item pernyataan nomor 1 sebesar $34.50 \%$ hal ini menunjukkan bahwa hampir setengahnya siswa dalam belajar tidak bergantung kepada orang lain. Persentase rata-rata jawaban siswa untuk item pernyataan nomor 2 sebesar $27.00 \%$ hal ini menunjukkan hampir setengahnya siswa terlambat dalam mengumpulkan tugas. Persentase rata-rata jawaban siswa untuk item pernyataan nomor 3 sebesar $30.00 \%$ hal ini menunjukkan hampir setengahnya siswa diingatkan oleh orang tua belajar matematika. Persentase rata-rata jawaban siswa untuk item pernyataan nomor 4 sebesar $45.00 \%$ hal ini menunjukkan hampir setengahnya siswa terpacu setiap guru mengingatkan belajar matematika. Persentase rata-rata jawaban siswa untuk item pernyataan nomor 5 sebesar $34.00 \%$ hal ini menunjukkan hampir setengahnya siswa aktif dalam mencari tugas yang harus dikerjakan.

Persentase rata-rata jawaban siswa untuk item pernyataan nomor 6 sebesar $31.50 \%$ hal ini menunjukkan hampir setengahnya siswa malas mempelajari matematika. persentase 
rata-rata jawaban siswa untuk item pernyataan nomor 7 sebesar $26.50 \%$ hal ini menunjukkan hampir setengahnya siswa sering tidak mengumpulkan tugas. persentase rata-rata jawaban siswa untuk item pernyataan nomor 8 sebesar $27.00 \%$ hal ini menunjukkan hampir setengahnya siswa bersungguh-sungguh dalam mengerjakan tugas matematika. persentase rata-rata jawaban siswa untuk item pernyataan nomor 9 sebesar $34.50 \%$ hal ini menunjukkan hampir setengahnya siswa belajar matematika dari dorongan sendiri. Persentase rata-rata jawaban siswa untuk item pernyataan nomor 10 sebesar $27.00 \%$, hal tersebut menunjukkan hampir setengahnya siswa mengerjakan soal matematika tanpa diperintah.

Persentase rata-rata jawaban siswa untuk item pernyataan nomor 11 sebesar $26.00 \%$ hal ini menunjukkan bahwa hampir setengahnya siswa mengandalkan teman dalam mengerjakan tugas. Persentase rata-rata jawaban siswa untuk item pernyataan nomor 12 sebesar $36.00 \%$ hal ini menunjukkan hampir setengahnya siswa menganggap soal sulit sebagai tantangan. Persentase rata-rata jawaban siswa untuk item pernyataan nomor 13 sebesar $39.50 \%$ hal ini menunjukkan hampir setengahnya siswa membiarkan tugas tersebut kalau tidak bisa menyelesaikannya. Persentase rata-rata jawaban siswa untuk item pernyataan nomor 14 sebesar $40.50 \%$ hal ini menunjukkan hampir setengahnya siswa menganggap pembelajaran jarak jauh berbasis google classroom dapat membuat mengumpulkan tugas tepat waktu. Persentase rata-rata jawaban siswa untuk item pernyataan nomor 15 sebesar $26.00 \%$ hal ini menunjukkan hampir setengahnya siswa merasa putus asa ketika ada soal yang sulit.

Persentase rata-rata jawaban siswa untuk item pernyataan nomor 16 sebesar $26.50 \%$ hal ini menunjukkan hampir setengahnya siswa belajar ketika ada tugas saja. Persentase ratarata jawaban siswa untuk item pernyataan nomor 17 sebesar $25.50 \%$ hal ini menunjukkan hampir setengahnya siswa ketika ada ujian mereka pasti berhasil. Persentase rata-rata jawaban siswa untuk item pernyataan nomor 18 sebesar $28.50 \%$ hal ini menunjukkan hampir setengahnya siswa bahwa keberhasilan dalam belajar matematika ditentukan oleh diri sendiri. Persentase rata-rata jawaban siswa untuk item pernyataan nomor 19 sebesar $30.50 \%$ hal ini menunjukkan hampir setengahnya siswa mencontek dalam ujian. Persentase rata-rata jawaban siswa untuk item pernyataan nomor 20 sebesar $54.50 \%$ hal ini menunjukkan sebagian besar siswa bertanya kepada teman ketika ada materi yang belum dipahami.

\section{KESIMPULAN}

Berdasarkan hasil perhitungan, diperoleh persentase rata-rata jawaban siswa secara keseluruhan sebesar $32.53 \%$ hal tersebut menunjukkan, bahwa persentase rata-rata 
kemandirian belajar siswa sebesar $32.53 \%$ artinya hampir setengahnya siswa telah memiliki kemandirian dalam belajar matematika. Meskipun demikian, kemandirian belajar siswa masih perlu diingatkan. Oleh karena itu dalam penelitian ini, dapat disimpulkan bahwa pembelajaran Jarak Jauh berbasis Google Classroom dapat meningkatkan kemampuan komunikasi matematis siswa. Data peningkatan tersebut berada pada kategori rendah

\section{REFERENSI}

Ansari, B. I. (2018, November). Komunikasi Matematik. Banda Aceh: Yayasan Pena. Alfabeta, CV.

Isjoni. (2019). Pembelajaran Kooperatif. Yogyakarta: Pustaka Pelajar.

Kemendikbud. (2020, maret 24). Retrieved from Surat Edaran Nomor 4 Tahun 2o2o Tentang Pelaksanaan Kebijakan Pendidikan Dalam Masa Darurat Penyebaran Co Ro Naviru S D/Sease (Covid-19).

Kurniawan, A. (2020). Pemanfaatan Jb Class Untuk Mendorong Kemandirian Belajar Siswa Dalam Pembelajaran Daring Di Masa Pandemi Covid-19. Vol. 5, No.1 Edisi Khusus Kbm Pandemi Covid-19, 5, 1-8. (30 juni 2020)

Munir. (2009). Pembelajaran Jarak Jauh Berbasis Teknologi Informasi Dan Kominukasi. Bandung: Alfabeta.

Oktavian, I. F. (2019). Pembelajaran Matematika Dengan Menggunakan Pendekatan Open Ended Untuk Meningkatkan Kemampuan Berfikir Kreatif. Subang.

Putri, G. K., \& Dewi, Y. A. (2019). Pengaruh Model Pembelajaran Jarak Jauh Berbasis Google Classroom. Al-Fikrah Vol. 2 No. 1, Juni 2019: 60-79, 2, 61-79. (30 juni 2020)

Rahayu, S. P. (2017). Penerapan Pendekatan Problem Posing Untuk Meningkatkan Kemampuan Komunikasi Matematis Siswa. Subang.

Ranti, M. G. (2015). Meningkatkan Kemampuan Komunikasi Matematis Siswa Menggunakan Strategi Writing To Learn Pada Siswa Smp. Vol. 1, No 2, Mei-Agustus 2015, 1, 96-102. (19 juni 2020)

Sugiyono. (2017). Metode Penelitian Kuantitatif, Kualitatif, dan R\&D. Bandung :

Yudhanegara, K. E. (2015). Penelitian Pendidikan Matematika. (Anna, Ed.) Bandung: PT Refika Aditama. 